\title{
Laser Hemorrhoidoplasty of a Single Surgical Centre
}

\section{Tek Cerrahi Merkezin Lazer Hemoroidoplasti Deneyimleri}

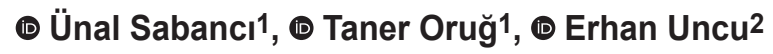 \\ ${ }^{1}$ Kadıköy Medicana Hospital, Clinic of General Surgery, İstanbul, Turkey \\ ${ }^{2}$ Göztepe Medicana Hospital, Clinic of General Surgery, İstanbul, Turkey
}

\section{HIIIIII| ABSTRACT}

Aim: The aim of our study was to assess the outcome of hemorrhoidal dearterialization, achieved by a dedicated laser energy device.

Method: From February 2013 to December 2017, 441 patients with second- or third-degree hemor-rhoids were studied. The primary end point was a reduction in the bleeding rate; secondary end points were; reduction in pain and recurrence of the symptoms which patients complaint. The procedure was carried out as 1-day surgery. A 1,470 nm diode laser device was employed to seal the terminal branch-es of the hemorrhoidal arteries. Follow-up was scheduled at 1 and 4 weeks, 3 and 6 months.

Results: Two early postoperative bleeding (2/441) which recquired surgical intervention, Late com-plications were Eight (8/441) thrombosed hemorrhoids that resolved medically and recurrence of the symptoms which patients suffer in 10 patients (10/441). Postoperative pain was recorded by using a 10-point visual analog scale (VAS) on which 0 represents no pain and 10 represents the worst pain imaginable. VAS protocol was followed up after 1 week, 1 month. Mean pain score was 0.65 in postoperative 1 week and decreased gradually. All patients were discharged on the day of surgery.

Conclusion: The hemorrhoid laser procedure was effective in improving bleeding and pain symp-toms in patients with Grade II and III hemorrhoids, but prospective randomized controlled studies are needed for evidence based conclusions.

Keywords: Dearterialization, hemorrhoidal disease, laser

\section{HIIIII| ÖZ}

Amaç: Çalışmamızın amacı, özel bir lazer enerji cihazı ile gerçekleştirilen hemoroidal arteri kapatma işleminin sonucunu değerlendirmekti.

Yöntem: Şubat 2013'ten Aralık 2017'ye kadar 441 Grade 2-3 hemoroid hastası çaşılmaya dahil edildi. Birincil hedef kanamanın azalması; ikincil hedefler ağrının ve hasta şikayetlerinin nüksünün azalması idi. İşlem 1 günlük cerrahi girişim olarak uygulandı. Hemoroidal arterlerin terminal uçlarını kapatmak için $1470 \mathrm{~nm}$ diod lazer cihazı kullanıldı. Hastalar 1. hafta, 4. hafta 3 ve 6. aylarda takip edildi.

Bulgular: İki olguda postoperatif erken kanama (2/441) oldu ve bunlar cerrahi girişim gerektirdi. Geç komplikasyon olarak Sekiz olguda (8/441) tromboze hemoroid gelişti, bunlar medikal tedavi ile düzeldi. On olguda (10/441) ameliyat öncesi şikayetleri tekrarladı (nüks). Postoperatif ağrı 10 üzerinden görsel analog ölçek (VAS) ile kaydedildi. 0: hiç ağrı yok, 10: en kötü ağrı olarak değerlendirildi. VAS skoru 1 hafta ve 1 ay sonra da tekrarlandı. Ağrı skoru postoperatif 1. haftada 0.65 idi ve giderek azaldı. Tüm hastalar ameliyat günü taburcu edildiler.

Sonuç: Hemoroidal laser girişimi Grade 2 ve 3 hemoroidlerde kanama ve ağrıyı tedavi etmede etkili bir yöntemdir, fakat kanıta dayalı sonuçlar elde etmek için prospektif randomize kontrollü çalışmalara gereksinim vardır.

Anahtar Kelimeler: Dearterialization, hemoroidal hastalık, lazer

\section{Introduction}

Haemorrhoidal disease (HD) is a common disorder that affects millions of people worldwide and causes significant disability. Further, rectal bleeding, pain, anal irritation and prolapse, which can lead to an altered quality of life, are the most common symptoms. ${ }^{1}$ Despite the fact that there are multiple techniques used to treat $\mathrm{HD}$, there are still contradictory views about the ideal procedure, i.e. the most effective and without causing discomfort to the patient. ${ }^{2,3}$ Conventional excisional haemorrhoidectomy $y^{4,5}$ is an

Address for Correspondence/Yazışma Adresi: Ünal Sabancı, MD, 
effective treatment for HD, but, severe postoperative pain is commonly experienced. ${ }^{6}$ Morinaga et al. ${ }^{7}$ first identified a non-excisional technique, known as haemorrhoidal artery ligation, in the 1990s. This approach is based on reducing the supply of blood to the terminal branches of the haemorrhoidal arteries using Doppler-guided identification and surgical ligation of the vessels. Further, the subsequent decrease in the blood supply results in a reduction in the volume of the haemorrhoidal plexus, resulting in shrinkage of the haemorrhoidal cushions. ${ }^{8,9}$ Giamundo et al. ${ }^{10,11}$ have also recently suggested a Doppler-guided laser dearterialization of the terminal branches of the superior haemorrhoidal arteries (HeLP procedure). Thus, the goal of our single-centre retrospective study was to report the results of HeLP in patients with symptomatic second- and third-degree haemorrhoids.

\section{Materials and Methods}

In this study, 441 patients suffering from Grades II and III HD were included. Furthermore, the criteria for exclusion were fourth-degree and prolapsed haemorrhoids and any coexisting anal conditions such as anal fissure or fistula. In addition, all those procedures were done by three surgeons. Preoperatively, a thorough medical history was taken, and patients underwent routine blood tests and physical examination (inspection, palpation and digital rectal examination). Anoscopy was routinely conducted, but colonoscopy was only performed in selected patients.

Two enemas (135 mL) were administered preoperatively (on the evening before surgery and early on the morning of the procedure). Antibiotic prophylaxis with $500 \mathrm{mg}$ metronidazole was regularly administered 30 minutes before the procedure.

Mask anaesthesia was administered to the patients in lithotomy position. Following anal retractor insertion, a 2-mm skin incision close to the anal verge was performed. Up to the apex of haemorrhoidal cushion, the laser probe was promoted. Moreover, four to six beams per pack were applied in 3 seconds (6W $1470 \mathrm{~nm}$ diode laser) during proximal and distal retraction of the probe form (Figure 1). After the procedure, an anal spongostan was inserted into the anal canal, and $10 \mathrm{cc}$ of local anaesthetic was injected around the anus. The mean procedure time was 7 (5-12) minutes. After 4-8 hours of surgery, the patients were discharged.

Data and procedure-related data of the patients, rates of peri- and postoperative complications, and pre- and postoperative symptoms were collected. A 10-point visual analogue scale (VAS) was used to record postoperative pain, where 0 represents no pain and 10 represents the worst pain imaginable. After 1 week and 1 month, the VAS protocol was followed up.

Recurrence was defined as any symptom that resolved after the surgical procedure but recurred during follow-up and caused discomfort.

All patients were informed about the procedure, and certificate of consent was taken for every patient.

\section{Statistical Analysis}

The t-test for continuous variables and $\mathrm{x} 2$ test for categorical values were used to compare preoperative and postoperative outcomes. A p value below 0.05 was considered statistically significant. Moreover, the analysis was conducted using standard statistical software for biomedical research (SPSS for MAC advanced statistical software, release 20.0, SPSS Inc., Chicago, IL, USA).

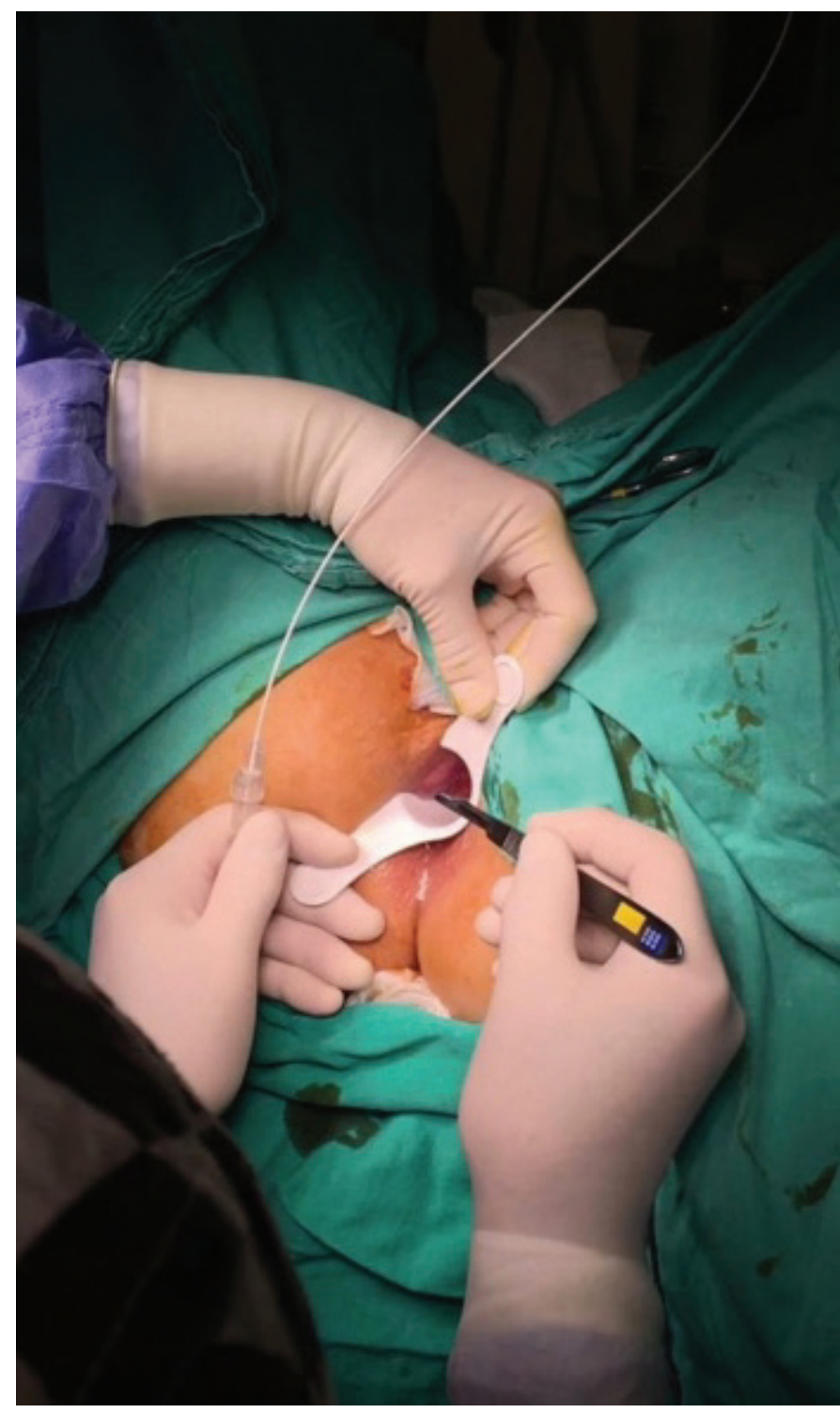

Figure 1. 6W $1470 \mathrm{~nm}$ diode laser application 


\begin{tabular}{|c|c|c|c|}
\hline VAS score & Day 1 (patient\%) & Day 7 (patient\%) & 1 month (patient\%) \\
\hline $0-1$ & $110 / 441(25 \%)$ & $419 / 441$ (95\%) & $441 / 441(100 \%)$ \\
\hline$>5$ & $0 / 441(0 \%)$ & $0 / 441(0 \%)$ & $0 / 441(0 \%)$ \\
\hline
\end{tabular}

VAS: Visual analogue scale

\section{Results}

Between 2013 and 2017, 441 patients [251 (57\%) male and 190 (43\%) female] were operated on with laser coagulation at our facility. Moreover, 10 patients had Grade II (3\%) while 431 had Grade III (97\%) disease, with a mean age of 43.1 (22-71).

The hemorrhoid laser procedure (HLP) was performed on 441 patients who had symptomatic Grades II and III haemorrhoids with a mean age of $43.1 \pm 11.3$ (range: 2271 ) years. The mean surgical time was $7.36 \pm 3.7 \mathrm{~min}$. In two cases, early postoperative bleeding was observed and surgical haemostasis was required. Postoperative nonsteroid analgesics were administered on demand for 2-5 days. There was no major pain reported that required narcotic medication. In any of the cases, no blood transfusions were needed. Over the first year, ten patients' symptoms recurred (2.3\%).

\section{Discussion}

Our single-centre study confirms the safety and efficacy of the HLP procedure for the treatment of haemorrhoids. Moreover, it showed that the good results are maintained in the long term and that patients thought there was a good level of improvement after surgery.

Over the past few decades, several non-excisional techniques for treating HD were developed. These surgical approaches are focused on the replacement of haemorrhoidal cushions within the anal canal, such as in Longo's procedure ${ }^{12,13}$ or in the reduction in the arterial inflow in the haemorrhoidal plexus obtained by ligation of the terminal branches of the haemorrhoidal arteries under Doppler guidance. ${ }^{14}$ The most effective surgical procedure for HD, namely, excisional haemorrhoidectomy, is associated with moderate to severe postoperative pain that is difficult to manage at home. Unfortunately, an efficient and painless procedure has not yet been identified. Dearterialization techniques have demonstrated good results in the treatment of second- and third-degree haemorrhoids. ${ }^{15}$ However, when evaluated in randomized trials, the postoperative course was not significantly different from that after the excisional procedures. ${ }^{16,17}$ Recently, the HLP technique was introduced as a new minimally invasive dearterialization procedure, where sealing of the arterial flow to the haemorrhoidal plexus was obtained by laser photocoagulation of the terminal branches of the superior rectal artery. The literature demonstrated that this procedure is effective, with low intraoperative and postoperative morbidity and little postoperative pain expected. ${ }^{18}$ Postoperatively, preoperative bleeding and pain were greatly improved, and the benefit observed after 3 months was maintained over the long term. ${ }^{19}$ In this study, we included Grades II and III haemorrhoid patients, but from our previous studies, we observed minimal retraction effect on mucosal prolapse with HLP. We also reported recurrence of symptoms in ten patients (2.3\%), all during the first year. This is comparable with short-term results of other non-excisional procedures..$^{20}$ The reasons for recurrences are not known. In this procedure, we applied four to six beams (in 3 seconds) to each haemorrhoid. This is up to the expertise of the surgeon. This aspect, we assume, is the lack of this technique. Finally, it could be argued that the HLP kit is rather expensive (300 dollars). However, HLP is associated with a shorter operating period and hospital stay than other non-excisional procedures, and little postoperative care is required. Moreover, as regards the social cost of the treatment, patients resumed normal habits and work practices earlier. In the short term, the present study showed a good resolution of symptoms. However, to evaluate the accuracy of this procedure, studies with longer follow-up as well as randomized controlled trials are needed.

\section{Conclusion}

This single-centre study has shown that the HLP procedure in patients with second- and third-degree haemorrhoids is effective and is associated with a short operative and recovery time, can be carried out in a day surgery setting with minor intra- and postoperative pain, and provides a significant improvement in symptoms. Since this is not a prospective randomized controlled study, the evidence value is low. The initial results of the study are maintained in the long term; therefore, as an author recommendation, this procedure could be regarded as an alternative to more invasive interventions in early-stage HD.

\section{Ethics}

Ethics Committee Approval: Since it is a retrospective study, ethics committee approval is not required. 
Informed Consent: All patients were informed about the procedure, and certificate of consent was taken for every patient.

Peer-review: Internally peer reviewed.

\section{Authorship Contributions}

Surgical and Medical Practices: Ü.S., T.O., E.U., Concept: Ü.S., Design: ÜS., Analysis or Interpretation: Ü.S., Literature Search: Ü.S., Writing: Ü.S.

Conflict of Interest: No conflict of interest was declared by the authors.

Financial Disclosure: The authors declared that this study received no financial support.

\section{References}

1. Johanson JF, Sonnemberg A. The prevalence of hemorrhoids and chronic constipation. An epidemiological study. Gastroenterology 1990;98:380386

2. Madoff RD, Fleshman JW. Clinical Practice Committee, American Gastroenterological Association. American Gastroenterological Association technical review on the diagnosis and treatment of hemorrhoids. Gastroenterology 2004;126:1463-1473.

3. Lumb KJ, Colquhoun PH, Malthaner R, Jayaraman S. Stapled versus conventional surgery for hemorrhoids. Cochrane Database Syst Rev 2006;4:CD005393

4. Milligan ETC, Morgan CN, Jones LE et al. Surgical anatomy of the anal canal and the operative treatment of hemorrhoids. Lancet 1937;230:11191123.

5. Ferguson JA, Heaton JR. Closed hemorroidectomy. Dis Colon Rectum 1959:2:176-179.

6. Gerbershagen HJ, Aduckathil S, van Wijck AJ, Peelen LM, Kalkman CJ, Meissner W. Pain intensity on the first day after surgery: a prospective cohort study comparing 179 surgical procedures. Anesthesiology 2013:118:934-944

7. Morinaga K, Hasuda K, Ikeda T. A novel therapy for internal hemorrhoids: ligation of the hemorrhoidal artery with a newly devised instrument (Moricorn) in conjunction with a Doppler flowmeter. Am J Gastroenterol 1995;90:610-613

8. Sohn N, Aronoff JS, Cohen FS, Weinsterin MA. Transanal hemorrhoidal dearterialization: non-excisional surgery for the treatment of hemorrhoidal disease. Am J Surg 2001;182:515-519.

9. Aigner F, Bodner G, Conrad F, Mbaka G, Kreczy A, Fritsch H. The superior rectal artery and its branching pattern with regard to its clinical influence on ligation techniques for internal hemorrhoids. Am J Surg 2004;187:102 108
10. Giamundo P, Cecchetti W, Esercizio L Fantino G, Geraci M, Lombezzi R, Pittaluga M, Tibaldi L, Torre G, Valente M. Dopplerguided hemorrhoidal laser procedure for the treatment of symptomatic hemorrhoids: experimental background and short-term clinical results of a new miniinvasive treatment. Surg Endosc 2011;25:1369-1375.

11. Giamundo P, Salfi R, Geraci M, Tibaldi L, Murru L, Valente M. The hemorrhoid laser procedure technique vs rubber band ligation: a randomized trial comparing 2 mini-invasive treatments for second- and third-degree hemorrhoids. Dis Colon Rectum 2011;54:693-698.

12. Sutherland LM, Burchard AK, Matsuda K, Sweeney JL, Bokey EL, Childs PA, Roberts AK, Waxman BP, Maddern GJ. A systematic review of stapled hemorrhoidectomy. Arch Surg 2002;137:1395-1406.

13. Corman ML, Gravié JF, Hager T, Loudon MA, Mascagni D, Nyström PO, Seow-Choen F, Abcarian H, Marcello P, Weiss E, Longo A. Stapled haemorrhoidopexy: a consensus position paper by an international working party: indications, contra-indications and technique. Colorectal Dis 2003;5:304-310.

14. Dal Monte PP, Tagariello C, Sarago M, Giordano P, Shafi A, Cudazzo E, Franzini M. Transanal haemorrhoidal dearterialisation: nonexcisional surgery for the treatment of haemorrhoidal disease. Tech Coloproctol 2007;11:333-338

15. Giordano P, Overton J, Madeddu F, Zaman S, Gravante G. Transanal hemorrhoidal dearterialization: a systematic review. Dis Colon Rectum 2009;52:1665-1671.

16. De Nardi P, Capretti G, Corsaro A, Staudacher C. A prospective, randomized trial comparing the short- and long-term results of Dopplerguided transanal hemorrhoid dearterialization with mucopexy versus excision hemorrhoidectomy for grade III hemorrhoids. Dis Colon Rectum 2014:57:348-353

17. Elmér SE, Nygren JO, Lenander CE. A randomized trial of transana hemorrhoidal dearterialization with anopexy compared with open hemorrhoidectomy in the treatment of hemorrhoids. Dis Colon Rectum 2013:56:484-490

18. De Nardi P, Tamburini AM, Gazzetta PG, Lemma M, Pascariello A, Asteria CR. Hemorrhoid laser procedure for second- and third-degree hemorrhoids: results from a multicenter prospective study. Techniques in Coloproctology 2016;20:455-459.

19. Maloku H, Gashi Z, Lazovic R, Islami H, Juniku Shkololli A. Laser Hemorrhoidoplasty Procedure vs Open Surgical Hemorrhoidectomy: a Trial Comparing 2 Treatments for Hemorrhoids of Third and Fourth Degree . Acta Informatica Medica 2014;22:365

20. Crea N, Pata G, Lippa M, Chiesa D, Gregorini ME, Gandolfi P. Hemorrhoidal laser procedure: short- and long-term results from a prospective study. Am J Surg 2014;208:21-25. 